鹿児島県に括ける乳児死亡についての知見補遺

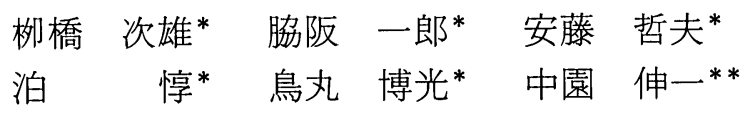

\title{
A Supplemental Study on the Infant Mortality \\ Figures in Kagoshima Prefecture
}

\section{Tsuguo YANAGIHASHI*, Ichiro WAKISAKA*, Tetsuo ANDO*, Tsutomu TOMARI*, Hiromitsu TORIMARU* and Shin-ichi NAKAZONO**}

Using the mortality statistics issued by the Kagoshima prefectural government, the relationships between infant, neonatal or early neonatal mortality rate for a 15 -year period 1971 to 1985 and the sex ratio at birth, the indicators of selected socioeconomic conditions or the measures of some ionic concentrations in drinking water were examined among a total of 96 local authority areas (city, town or village). The following results were obtained.

1) Among the 96 local authority areas, the sex ratio at births was positively correlated to the mortality rates for male's early neonates, male's, female's or total neonates and female's infants, respectively.

2) The percentage of girls or boys who enter senior high schools was inversely correlated to each of the early neonatal, neonatal and infant mortality rates. However, this correlation was not significant for male's early neonatal mortality rate only.

3) The percentage of junior childbearings was inversely correlated to female's or total neonatal mortality rate while that of senior childbearings was positively correlated to male's infant mortality rate.

4) Of the 13 ionic concentrations in drinking water, only 3 ions were significantly correlated to early neonatal, neonatal or infant mortality rate, in that, $\mathrm{Cl}^{-}$was positively correlated to the mortality rates for female's and total neonates and female's infants, $\mathrm{CO}_{3}{ }^{--}$negatively to total early neonatal mortality rate and $\mathrm{Ca}^{++}-\mathrm{Na}^{+}$negatively to the mortality rates for female's or total neonates and female's infants.

5) Results of multiple regression analysis showed that the mortality rates for infants, neonates and early neonates were attributed to none of the 13 ionic concentrations in drinking water.

* 鹿児島大学医学部公臭衛生学教室

** 鹿児島大学医学部小児科学教室

* Department of Public Health, Faculty of Medicine, Kagoshima University

** Department of Pediatrics, Faculty of Medicine, Kagoshima University 


\section{Iはじめに}

乳児死亡率は母子保健領域で重要視されている だけでなく,広くその地域の保健衛生状態の程度, 更には生活・文化水準を表わす指標とされてきた。 しかし，近年日本に扮いては母子保健事業の発展 により，地域の生活文化の指標とは必ずしもい充 ないような状態になってきた。

我が国の乳児死亡率は，諸外国に例をみない急 速度で低下し，現在では世界に捛ける最低率国の グループに入った，それでもな拉，国内的には出 生千対 $3 \sim 4$ の地域格差が，また市部・郡部差も みられる。一方，鹿児島県内に颃いても市町村レ ベルで地域間の格差がみられる。

鹿児島県に打ける乳幼児死亡率については 1968～1985年の資料をもとに脇阪ら (1988，1989， 1990）が詳細に検討を加方報告している.

本研究は, 鹿児島県の市町村単位で, 乳児死亡 を早期新生児, 新生児及び乳児の 3 種につき男女 児別死亡率を求め, 上級学校進学率, 母の年齢階 層別出産割合, 出生性比 (以下単に性比と記す), 公共飲用水の性状などの要因との関連を調べたも のである。

\section{II 資料及び方法}

本研究で用いた資料は鹿児島県衛生統計年報 （鹿児島県保健環境部，1971～1985）の昭和46年か ら60年までの 15 編である。これらの資料から15年 間の合計の各市町村の乳児死亡率を出生千対で求 めた。 ま,た, 同様に出生時の性比と母の年齢階層 別出産割合をも求めた。

市町村単位での高等学校などの上級学校進学率 (以下単に進学率と記す) は統計鹿児島(鹿児島県 統計協会，1971～1985）の「学校基本調査の概要」 から15年間の合計により男女別に算出した。

また, 各市町村の人口密集地区から领用水を採 取し，含有する $\mathrm{Na}^{+}, \mathrm{K}^{+}, \mathrm{Ca}^{++}, \mathrm{Mg}^{++}, \mathrm{Cl}^{-}$,

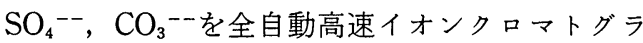
フィー（東ソーHLC-601, ·東京)を用いて測定し た（梸橋ら，1989，1990）。

\section{III 結 果}

地域毎の乳児死亡率の概況として，図 1 に男女 を併せた乳児死亡率を 5 段階に分けて市町村単位 で示した，県都鹿児島市とその隣接する周辺部が 総じて死亡率が低い，医療機関に恵まれない離島 にも死亡率の低いところがある一方，離島の 2 無 医村で高率である。乳児死亡率出生千対 9 未満は 15 市町村 ( 2 市 12 町 1 村)。 9 以上 12 未満は 26 市町 ( 7 市19町)，12以上 15 未満は30市町村 ( 4 市 25 町 1 村), 15 以上 18 未満は 18 市町村 ( 1 市 12 町 5 村), 18 以上は 7 町村 ( 5 町 2 村) である。このうち同 じ期間に括ける全国平均の乳児死亡率である 8.912 （国民衛生の動向，1988）より低いところが 15市町村であった。

乳児の死亡を男児，女児及び男女を併せたそれ ぞれで早期新生児死亡, 新生児死亡及び乳児死亡 の 3 種に分けて, 都合 9 種の死亡率を求めたもの と, 環境要因と考兄られる頂目との関係を示した ものが表 1 である.

早期新生児死亡率については，男児の場合には 性比と有意の正相関を，女児の場合には男女それ ぞれの進学率と有意の負相関を, 男女児を併せた 場合には男女それぞれの進学率の外に水の $\mathrm{CO}_{3}$-ーの間で有意の負相関を認めた。

新生児死亡率については，男児の場合には，性 比と有意の正相関を，女児の場合には男女それぞ れの進学率，20歳未満の出産割合（以下若年婦人 の出産割合と記す）とは有意の負相関を認め, 性 比々有意の正相関を認めた。更に水の $\mathrm{Cl}^{-}$と有意 の正相関を, $\mathrm{Ca}^{++}-\mathrm{Na}^{+}$と有意の負相関を認め た。男女児を併せた新生児死亡率と環境要因との 相関は女児の場合と全く同様な結果であった。

乳児死亡率については，男児の場合には男女そ れぞれの進学率と有意の負相関を，35歳以上 $(40$ 歳以上もここに含む) と 40 歳以上の高年婦人の出 産割合と有意の正相関を認め, 女児の場合には男 女それぞれの進学率とは有意の負相関を，性比と は有意の正相関を, $\mathrm{Cl}^{-}$と有意の正相関を, $\mathrm{Ca}^{++}$ 一 $\mathrm{Na}^{+}$と有意の負相関を認め, 男女児を併せた場 


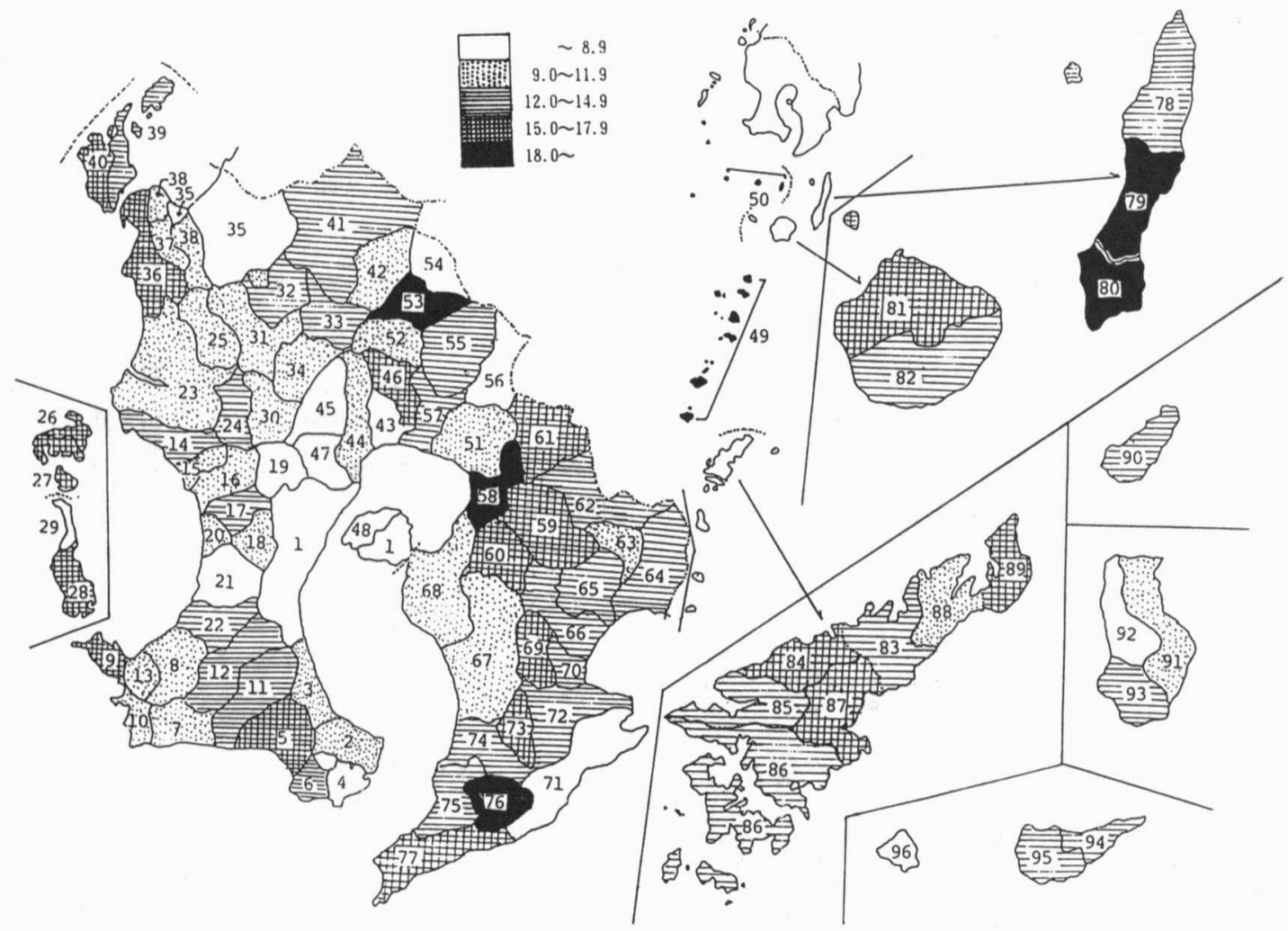

図 1 昭和 46 年から昭和 60 年迄の乳児死亡率 (出生 1,000 対)

合には男女それぞれの進学率と有意の負相関を認 めた.

各乳児死亡率を説明する19種の因子との関連性 の強さをみるために, SAS 統計パッケージ PROC REGのステップワイズ法による重回㷌分析を行 い，その結果を表 2 に掲げた，採択基準を $15 \%$ と $5 \%$ の 2 種とし, 前者の場合を上段に, 後者の場 合を下段に示した。

早期新生児死亡率については，男児の場合には 採択基準15\%ではマイナス係数はなく，プラス係 数として性比があげられ, その寄与率は $4.4 \%$ であ り，採択基準 $5 \%$ の場合にも同様であった，女児 の場合には採択基準15\%では女子の進学率, 若年 婦人の出産割合, $\mathrm{K}^{+}$がマイナス係数で, プラス係 数はなく，その寄与率は15.6\%であり，採択基準 $5 \%$ 場合には女子の進学率のみがマイナス係数
に採択され，その寄与率は $6.2 \%$ あっった，男女児 を併せた場合には採択基準15\%では男子の進学 率, 若年婦人の出産割合, $\mathrm{CO}_{3}^{--}$がマイナス係数, 性比はプラス係数であり，寄与率は $20.5 \%$ あ゙あ た. 採択基準 $5 \%$ の場合には男子の進学率，若年 婦人の出産割合がマイナス係数として採択され， プラス係数はなく，寄与率は $16.4 \%$ であった。

新生児死亡率については，男児の場合には採択 基準15\%では男子の進学率がマイナス係数, 性比 がプラス係数で, 寄与率は7.8\%であり, 採択基準 $5 \%$ では性比だけか゚プラス係数に採択され，その 寄与率は $4.7 \%$ であった. 女児の場合には女子の進 学率, 若年婦人の出産割合, $\mathrm{Mg}^{++}+\mathrm{Ca}^{++}$がマイナ ス係数, 性比と $\mathrm{Cl}^{-}$がプラス係数で, 寄与率は $41.0 \%$ であり, 採択基準 $5 \%$ では飲用水中の含有 イオンは採択されず, 女子進学率と若年者出産割 
表 1 乳児の死亡率と社会環境要因, 出生性比及び飲料水中含有イオンとの関係

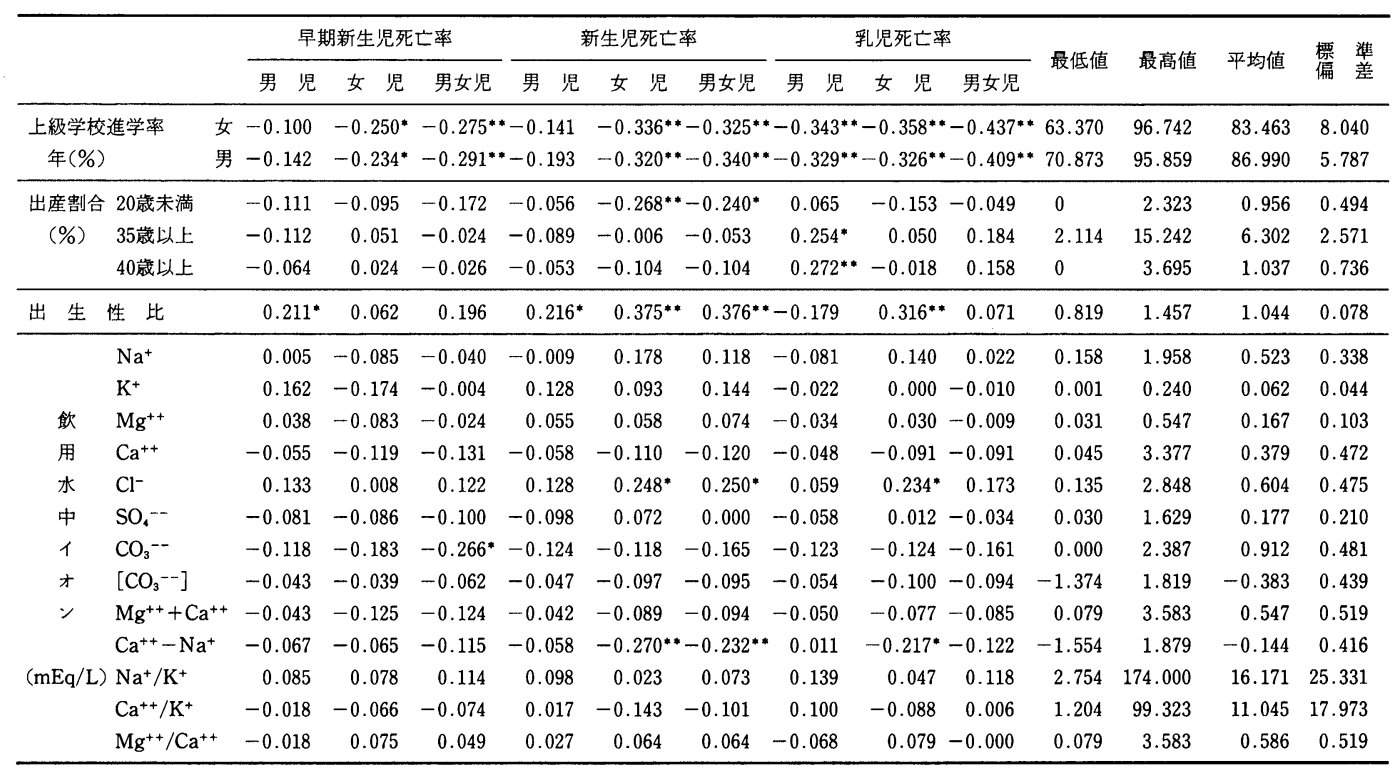

註： $\left[\mathrm{CO}_{3}{ }^{--}\right]=\mathrm{Na}^{+}+\mathrm{K}^{+}+\mathrm{Ca}^{++}+\mathrm{Mg}^{++}-\left(\mathrm{Cl}^{-}+\mathrm{SO}_{4}{ }^{--}\right)$

表 2 乳児の死亡率別による社会環境要因, 出生性比及び飲料水含有イオンの重回帰分析

\begin{tabular}{|c|c|c|c|c|c|c|c|c|c|c|}
\hline & & \multicolumn{3}{|c|}{ 早期新生児死亡率 } & \multicolumn{3}{|c|}{ 新生児死亡率 } & \multicolumn{3}{|c|}{ 乳児死亡率 } \\
\hline & & 児 & 女 児 & 男女計 & 児 & 女 児 & 男女計 & 男 児 & 女 児 & 男女計 \\
\hline \multirow{3}{*}{$\begin{array}{l}\text { 榽 } \\
\text { 基 } \\
\text { 準 } \\
15 \\
\%\end{array}$} & $\begin{array}{l}\text { マイナス } \\
\text { 係数 }\end{array}$ & & $\begin{array}{l}\text { 女子嚄学率 } \\
\text { 年者の出 } \\
\text { 産割合 } \\
\mathrm{K}^{+} \text {濃度 }\end{array}$ & $\begin{array}{l}\text { 男子準学率 } \\
\text { 若年者の出 } \\
\text { 産割合 } \\
\mathrm{CO}_{3}^{--} \text {-濃度 }\end{array}$ & 男子進学率 & $\begin{array}{c}\text { 女子進学率 } \\
\text { 若年者の出 } \\
\text { 産割合 } \\
\mathrm{Mg}^{++}+ \\
\mathrm{Ca}^{++} \text {濃度 }\end{array}$ & $\begin{array}{c}\text { 女子萑学率 } \\
\text { 年者の急 } \\
\text { 産割合 }\end{array}$ & $\begin{array}{l}\text { 女子進学率 } \\
\text { 性比 } \\
{\left[\mathrm{CO}_{3}^{--}\right]} \\
\text {濃度 }\end{array}$ & $\begin{array}{c}\text { 女子惹年堆学率 } \\
\text { 産劃合 }\end{array}$ & $\begin{array}{c}\text { 女子㔼学率 } \\
\text { 若年者の出 } \\
\text { 産割合 } \\
\mathrm{Na}^{+} \text {濃度 }\end{array}$ \\
\hline & $\begin{array}{l}\text { プラス } \\
\text { 係数 }\end{array}$ & 性比 & & 性比 & 性比 & $\begin{array}{l}\text { 性比 } \\
\mathrm{Cl}^{-} \text {濃度 }\end{array}$ & 性比 & & 性比 & $\mathrm{Cl}^{-}$濃度 \\
\hline & 寄与率 & $4.4 \%$ & $15.6 \%$ & $20.5 \%$ & $7.8 \%$ & $41.0 \%$ & $34.9 \%$ & $17.2 \%$ & $28.9 \%$ & $28.4 \%$ \\
\hline \multirow{3}{*}{$\begin{array}{c}\text { 採 } \\
\text { 基 } \\
\text { 準 } \\
5 \\
\%\end{array}$} & $\begin{array}{l}\text { マイナス } \\
\text { 係数 }\end{array}$ & & 女子進学率 & $\begin{array}{l}\text { 男子隻学率 } \\
\text { 年者の出 } \\
\text { 産割合 }\end{array}$ & & $\begin{array}{c}\text { 女子嚄学率 } \\
\text { 年者の出 } \\
\text { 産割合 }\end{array}$ & $\begin{array}{l}\text { 女子蒦学率 } \\
\text { 若年者の出 } \\
\text { 産割合 }\end{array}$ & 女子進学率 & $\begin{array}{l}\text { 女子萑学率 } \\
\text { 若年者の出 } \\
\text { 産割合 }\end{array}$ & $\begin{array}{l}\text { 女子進学率 } \\
\text { 若年者出 } \\
\text { 産割合 }\end{array}$ \\
\hline & $\begin{array}{l}\text { プラス } \\
\text { 係数 }\end{array}$ & 性比 & & & 性比 & 性比 & 性比 & & 性比 & \\
\hline & 寄与率 & $4.4 \%$ & $6.2 \%$ & $16.4 \%$ & $4.7 \%$ & $37.9 \%$ & $34.9 \%$ & $11.8 \%$ & $28.9 \%$ & $23.7 \%$ \\
\hline
\end{tabular}

合がマイナス係数に採択され寄与率は $37.9 \%$ で あった。男女児を併せた場合には女子の進学率, 若年婦人の出産割合がマイナス係数, 性比がプラ ス係数，寄与率は $34.9 \%$ であり，採択基準 $5 \%$ の 場合も全く同様の結果であった。

乳児死亡率については，男児の場合には採択基 準15\%では女子の進学率, 性比, $\mathrm{Mg}^{++}+\mathrm{Ca}^{++}+$
$\mathrm{Na}^{+}+\mathrm{K}^{+}$- $\left(\mathrm{SO}_{4}^{--}+\mathrm{Cl}^{-}\right)$で表わされる $\left[\mathrm{CO}_{3}\right]$ が マイナス係数で，プラス係数はなく，その寄与率 は17.2\%であり，採択基準 $5 \%$ の場合には女子の 進学率のみがマイナス係数であり，その寄与率は 11.8\%であった，女児の場合には採択基準15\%で は女子の進学率, 若年婦人の出産割合がマイナス 係数，性比がプラス係数で，寄与率は $28.9 \%$ であ 
り，採択基準 $5 \%$ でも同じ結果であった。男女児 を併せた場合には採択基準15\%では女子の進学 率, 若年婦人の出産割合, $\mathrm{Na}^{+}$がマイナス係数で, $\mathrm{Cl}^{-}$がプラス係数で, 寄与率は $28.4 \%$ であ，採択 基準 $5 \%$ の場合には女子の進学率, 若年婦人の出 産割合がマイナス係数で，プラス係数はなく，そ の寄与率は23.7\%であった。

\section{IV 考察}

今回，我々が用いた乳児死亡などの資料は昭和 46 年から 60 年までの 15 年間のものであり，この間 に離島の鹿島村では乳児死亡が 1 例もなかった。 仮に 1 例の死亡があると出生千対 11.363 となり， 全国のそれよりも高くなる。更にはまた三島村， 十島村で乳児死亡がそれぞれ 1 例ずつ少ないとそ の死亡率は23.255から11.627，30.534から22.900 へと減少することになる。15年間の延べ数であっ てもこのような現象がみられるのはこれらの村 が，人ロサイズが小さく，出生数が極端に少ない ためで，対象集団の人口が十分に大きくないとわ ずかの変化が大きな違いとして浮かび上がってく ることを意味する。

本県に拈ける乳児死亡率の高低の背景要因につ いては，既に脇阪ら（1988）が昭和43年から60年 までの18年間の市町村別死亡率は最高と最低で約 5 倍の開きがあり, 所得水準或いは医師密度との 間に負の有意相関があることから，乳児死亡率が 当時では社会経済水準をよく反映する指標であっ たことを報告した。

鹿児島県は多くの離島や僻地を抱え，雇用を充 分に確保できるような産業が少ない社会条件にあ る、そこで，このような不利な条件に加えて，教 育条件, 婦人の年龄階層別出産割合を要因として, また今まで調査してきた飲用水中の各種含有イオ ン濃度（栵橋ら：1989）を加兄て，これらが乳児 死亡に及ぼす影響を追及した。教育条件としては， 今回男女中学校卒業生の高等学校などの上級学校 への進学率の資料を得て死亡率との関係をみた。 その結果, 進学稡と早期新生児死亡率, 新生児死 亡率，乳児死亡率との間には負の相関関係がみら
れ，進学率が低いといら社会条件がこれらの死亡 に関連していることが示唆された。また各種乳児 死亡率を説明する因子を重相関分析した結果，概 して若年婦人の出産割合がマイナス因子として採 択された。進学率及び若年婦人の出産割合が各種 死亡率に関連していることは以下のことが考兄ら れよう。すなわち，我が国の教育環境整備に伴な い, 本県に招いても高等学校進学率の急増が認め られる（昭和 45 年：74.9\%，昭和60年：95.2\%)。 しかしながら, 本県には離島地域及び僻地が多く, 上級学校への通学が困難であることが中学校卒業 後, 地区内または地区外で就業して社会人になる 可能性を覞わせる。その結果, 経済的自立の時期 も早いので早婚が多くなり, 若年出産の割合が大 きくなることが死亡率にマイナス因子として関連 しているのかもしれない，総じて，若年出産の割 合, 高年齢出産の割合の大きいところは一次産業 従事者が多い離島, 僻地を多く抱えている町村に みられる，宮城県に打ける伊田（1977）の調査で は一次産業割合が新生児死亡率, 乳児死亡率, 低 体重児出生率と関連していることを報告してい る.

教育水準と所得水準，社会的地位とは概ね正の 関係があることはよく知られた事実であり，イス ラェルの最近の調查でも, 父母が教育を受けた期 間を $0 \sim 8$ 年の短期間, $9 \sim 10$ 年, 11 年以上に 3 区分すると，乳児の死亡率への相対危険度は短期 間の方が長期間の群よりも高いと述べている (Barell ら：1988)。我々の場合には進学率を見た ものであったが，乳児死亡率とは負相関があり， 重回㷌分析でもマイナス係数として採用された。 もし，乳児を失った両親が受けた学校教育レベル を個人情報として知ることが可能であったならば また異なった結果を得たかも知れない。

教育水準の低さが，一般には出産などに関する 知識や疾病, 健康への対処意識の低さを現わした り，所得の低いことと関係があるので，このこと が乳児の死亡を高めていたのであろう。確かに所 得水準或いは家庭収入と乳児死亡率とは相関する とする報告が多い(Naylorら：1967, Spiers： 
1974，脇阪ら：1988). Donabedian ら (1965) も 米国のボストン市に拈ける調查で, 新生児死亡率 について同様の報告をしている。

先に脇阪らは出生時の性比が乳児死亡に及ぼす ことはないものとして報告したが, 乳児を早期新 生児期，新生児期，乳児期に区分し，また男女別， 男女を併せたものとで性比と死亡率との相関を求 めてみると，9種の区分のうち 5 種に有意の正相 関が認められた。出生児の性比が高いことが乳児 死亡を高めるかのような関係が得られたことは, 性比の地域差, 時代差が乳児死亡率に影響すると も考兄られる。 Lenz (1923) は乳児死亡率が高け れば死亡率性比が低下することを報告している が，その理由は明確に説明されていない，単に男 児の方が女児よりも活発で危険な行動・行為をす ることで男児の死亡率が高いと考えるのはいきす ぎであろう。

本研究では, 高年齢出産割合が大きいことは乳 児死亡率を高める傾向にあることが示唆された。 高齢出産, 高年齢初産の危険性は産科学で説かれ ていることであるが，他方，若年出産割合の小さ いことが新生児死亡率を高めることに関わってい ることをどのように解釈すべきであろらか。一般 には，米国での Millerら（1985）の調查のように 13歳から17歳の 10 代の出産率は新生児死亡率とも 乳児死亡率とも正の有意相関を示すが，18，19歳 は10代であっても，この年齢の出産は乳児の死亡 とは関係がないともいわれている。

本研究では, 飲用水中の含有イオンのらち, $\mathrm{Cl}$ は乳児死亡と有意の正相関を示し, かつ重回帰分 析でもプラス係数として採択された。一方, $\mathrm{CO}_{3}$ と $\mathrm{Ca}-\mathrm{Na}$ は乳児の死亡率と有意の負相関を示す が, 重回帰分析では $\mathrm{CO}_{3},\left[\mathrm{CO}_{3}\right], \mathrm{Na}$ がマイナス 係数として採択されたので矛盾する結果となっ た.これについては $\mathrm{CO}_{3}$ を測定する上での問題か ら生じたものと考元られる。事実，我々の $\mathrm{CO}_{3}$ の 測定值と他のイオン量から間接的に求めた $\left[\mathrm{CO}_{3}\right]$ の值との関係は逆相関 $(\mathrm{r}=-0.447, \mathrm{p}<0.001)$ であった。

Crawford ら (1972) は英国の調査で, 地域の水
道供給の違いで水質が異なり, 硬度と $\mathrm{Ca}$ 含量は 乳児死亡率とは有意の負相関を示したと述べてお りまたElwood ら (1977) もカナダにおいて $\mathrm{Mg}$ は乳児死亡率と有意の負相関があったと報告して いる.一方, 米国のロスアンジェルスでの調査で, Allwright ら (1974) は水中含有イオンは乳児死亡 率のみならず新生児死亡率とも有意の相関がな かったとしており，同じく米国で広域的に調査を したSpiersら（1974）む水中イオンに関しては否 定的であって，乳児死亡と有意相関のあったもの は所得や工業化尺度等の社会経済的要因であった と報告している。我々の場合には早期新生児。新 生児，或いは乳児の死亡率と有意の相関を認めた 水中イオンは, $\mathrm{Cl}, \mathrm{CO}_{3}, \mathrm{Ca}-\mathrm{Na}$ のわずか 3 つで あり，硬度を表わす $\mathrm{Mg}+\mathrm{Ca}$ ，またはその成分の $\mathrm{Mg}, \mathrm{Ca}$ 単独とでも有意の相関を認めなかった。 重回帰分析では女児の新生児死亡率にとって $\mathrm{Mg}+\mathrm{Ca}$ がマイナス係数として関与していたが, 採択率 $5 \%$ と厳しくすると $15 \%$ 水準では関与して いた $\mathrm{Mg}+\mathrm{Ca}$ のみならず, 全ての含有イオンは棄 却され，乙かもその奇与率は小さかった。これら のことから乳児死亡率に関わる水中含有イオンの 役割は殆どないと考えてよいであろう。それとと もに, 本研究では15年間に起きた現象である乳児 死亡率を現時点に拈ける领用水の成分で断面的に 観察したことにも問題が残るだろう.

\section{V 結 び}

鹿児島県の昭和 46 年から 60 年まで 15 年間の衛生 統計資料を用いて，早期新生児，新生児及び乳児 の死亡と上級学校への進学率, 若年出産割合, 高 年出産割合, 出生時の性比, 公共飲用水の各種含 有イオンとの相関を調べ，以下の所見を得た。

1）早期新生児死亡率は，男児では性比と正相 関, 女児では進学率と負相関, 男女計では, 進学 率, $\mathrm{CO}_{3}^{--}$と負相関を認めた。

2）新生児死亡率は, 男児は早期新生児の場合と 同様であり, 女児及び男女計では進学率, 若年婦 人の出産割合, $\mathrm{Ca}^{++}-\mathrm{Na}^{+}$と負相関, 性比と $\mathrm{Cl}^{-}$と は正相関を認めた。 
3）乳児死亡率は, 男児では進学率之負相関, 高 年出産割合と正相関を，女児では進学率， $\mathrm{Ca}^{++}$ $\mathrm{Na}^{+}$と負相関，性比及び $\mathrm{Cl}^{-}$とは正相関を，男女計 では進学率と負相関を認めた。

4）重回帰分析では採択率15\%の場合には, 早期 新生児死亡率は, 男児では性比がプラス数, 女児 では女子の進学率, 若年出産割合, $\mathrm{K}^{+}$がマイナス 係数, 男女計では男子の進学率, 若年出産割合, $\mathrm{CO}_{3}$--がマイナス係数, 性比がプラス係数であっ た.

5）新生児死亡率は, 男児では男子の進学率がマ イナス係数，性比がプラス係数，女児では女子の 進学率, 若年出産割合, $\mathrm{Mg}^{++}+\mathrm{Ca}^{++}$がマイナス係 数, 性比と $\mathrm{Cl}^{-}$がプラス係数, 男女計では女子の進 学率, 若年出産割合がマイナス係数, 性比がプラ ス係数であった。

6）乳児死亡率は, 男児では女子の進学率, 性比, $\left[\mathrm{CO}_{3}{ }^{--}\right]$がマイス係数, 女児では女子の進学率, 若年出産割合がマイナス係数, 性比がプラス係数, 男女計では女子の進学率, 若年出産割合, $\mathrm{Na}^{+} か ゙ マ$ イナス係数， $\mathrm{Cl}^{-}$がプラス係数であった。

7）重回㷌分析で採択率を $5 \%$ とすると飲用水 中の各種イオン類は採択されず，乳児死亡率関連 要因としての寄与は極めて小さいものと判断し た。

なお，本論文の投稿には公益信託児玉記念基礎医学 研究助成基金の助成を受けた。

\section{文献}

Allwright, S.P.A., Coulson, A., Detels, R. \& Porter, C.E. (1974): Mortality and water-hardness in three matched communities in Los Angele, Lancet, II, 860-864

Barell, V., Wax, Y. \& Ruder, A. (1988): Analysis of geographic differentials in infant mortality rates. The Or Yehuda community, Am. J. Epideminol., 128, 218-230

Cleland, J. \& van Ginneken, J.K. (1988) : Maternal education and child survival in developing coun- tries: The search for pathways influence, Soc. Sci. Med., 27, 1357-1368

Crawford, M.D., Gardner, M.J. \& Sedgwick, P.A. (1972): Infant mortality and hardness of local water supplies, Lancet, I, 988-992

Donabedian, A., Rosenfeld, L.S. \& Souther, E.M. (1965): Infant mortality and socioeconomic status in a Metropolitan community, Public Health Reports, 80, 1083-1094

Elwood, J.M. (1977): Anencephalus and drinking water composition, Am. J. Epidemiol., 105, 460 $-468$

伊田八洲雄（1977）：乳児死亡率・低体重児出生率の 地域差, 日本公衛誌, 24, 357-364

鹿児島県統計課 (1970-1985)：統計鹿児島，昭和 45 -60 年, 鹿児島県統計協会, 鹿児島

厚生統計協会（1988）：厚生の指標, 臨時増刊号, 国 民衛生の動向，366，厚生統計協会，東京

Lenz, F. (1923)： Die Übersterblichkeit der Knaben im Lichte der Erblichkeitslehre, Arch. Hyg., 93, $126-150$

Miller, M.K. \& Stokes, C.S. (1985): Teenage fertility, socioeconomic status and infant mortality, J. Biosocial. Sci., 17, 147-155

Naylor, A.F. \& Myrianthopoulos, N.C. (1967): The relation of ethnic and selected socioeconomic factors to human birth-weight, Ann. Hum. Genet. London, 31, 71-83

Spiers, P.S., Wright, S.G. \& Siegel, D.G. (1974): Infant mortality and water hardness in the United States, Pediatrics, 54, 317-319

脇阪一郎, 梸橋次雄, 江口 智, 泊惇, 波多野浩 道(1988)：鹿児島県の乳児死亡率に関する一考察， 民族衛生，54, 143-152

脇阪一郎, 佐藤祐美, 梸橋次雄, 泊 嵉 (1989)：鹿 児島県における乳児死亡率の減少について，民族衛 生, 55, 91-99

脇阪一郎, 梸橋次雄, 安藤哲夫, 中原俊隆 (1990)：鹿 児島県に打ける飲用水の成分之循環系疾患死亡との 関係，民族衛生，55，244-252

椥橋次雄, 安藤哲夫, 泊 嵉, 脇阪一郎, 中園伸一 (1990)：出生性比に対する関連要因の研究一鹿児 島県の場合一，民族衛生，56, 189-198

（受稿 1990，8，2） 